\title{
KAJIAN AKADEMIS PERATURAN PELAKSANAAN CARA LAIN UNTUK MENGHITUNG PEREDARAN BRUTO YANG MENDUKUNG KEPATUHAN SUKARELA
}

\section{Furqon Nurhandono ${ }^{a}$, Darius Hariono Garda Perkasab, Tri Kurniawan Yulianto ${ }^{c}$}

a Direktorat Jenderal Pajak, Indonesia. Email: furqon.nurhandono@pajak.go.id b Direktorat Jenderal Pajak, Indonesia. Email: darius.harionoperkasa@pajak.go.id c Direktorat Jenderal Pajak, Indonesia. Email: tri.kurniawanyulianto@pajak.go.id

\begin{abstract}
Minister of Finance Regulation Number 15/PMK.03/2018 concerning Other Basis to Calculate Gross Income regulated determination of tax payable through indirect evidence other than evidence from bookkeeping. This regulation potentially become double edge sword for the tax authority's mission to collect revenues based on voluntary tax compliance. Based on the Slipery Slope Framework, if the tax authority maintains the 'cops and robbers' attitude, voluntary compliance tends to decrease (Kirchler, Hoelzl, and Wahl 2008). Conversely, voluntary compliance will increase if the tax authorities are perceived to be more efficient in detecting tax fraud and bringing justice. This study presents a literature review as a consideration basis for developing regulatory policies for subordinate regulations of PMK 15/2018 that support voluntary compliance. Based on a literature review subordinate regulations of PMK 15/2018 that support voluntary compliance must be reliable, objective and be sanctioned credibly under legitimate power.
\end{abstract}

\section{ABSTRAK}

Peraturan Menteri Keuangan Nomor 15/PMK.03/2018 tentang Cara Lain untuk Menghitung Peredaran Bruto mengatur pembuktian pajak terutang melalui bukti tidak langsung yaitu, bukti dari informasi selain pembukuan. Peraturan ini dapat menjadi dua mata pisau bagi misi otoritas pajak untuk mengumpulkan penerimaan berdasarkan kepatuhan pajak sukarela. Berdasarkan Slipery Slope Framework jika otoritas pajak mempertahankan sikap "cops and robbers" maka kepatuhan sukarela cenderung menurun (Kirchler, Hoelzl, \& Wahl, 2008). Sebaliknya, kepatuhan sukarela akan meningkat jika otoritas pajak dipersepsikan lebih efisien dalam mendeteksi kecurangan pajak dan menegakkan keadilan. Penelitian ini menyajikan kajian literatur sebagai dasar pengembangan kebijakan peraturan pelaksanaan PMK 15/2018 yang mendukung kepatuhan sukarela. Berdasarkan kajian literatur peraturan pelaksanaan PMK 15/2018 yang mendukung kepatuhan sukarela rela harus memenuhi syarat handal, objektif dan diberikan sanksi secara kredibel berdasarkan kekuatan terlegitimasi.

Kata kunci: metode tidak langsung, cara lain, peraturan perpajakan, kepatuhan sukarela 


\section{PENDAHULUAN}

\subsection{Latar Belakang}

Peraturan Menteri Keuangan Nomor 15/PMK.03/2018 tentang Cara Lain untuk Menghitung Peredaran Bruto (PMK 15/2018) cukup meresahkan karena seolah Pemerintah akan mengejar pajak secara agresif dan menyasar ke semua orang dengan segala jurus (Prastowo, 2018). Keresahan yang dirasakan masyarakat adalah hal yang wajar karena PMK 15/2018 tersebut mengatur kewenangan otoritas pajak untuk menentukan besarnya pajak penghasilan tanpa melalui bukti langsung, tetapi cukup dengan bukti tidak langsung (Smith, 2015). Kewenangan tersebut memungkinkan otoritas pajak untuk menentukan pajak bukan melalui pengujian terhadap pembukuan melainkan dari catatan kas dan bank, volume usaha, catatan harta, dan lain sebagainya (Smith, 2015).

Dalam sistem self assessment melalui Pasal 12 Undang-Undang Nomor 6 Tahun 1983 tentang Ketentuan Umum dan Tata Cara Perpajakan sebagaimana diubah dengan Undang-Undang Nomor 16 Tahun 2009 (UU KUP), negara memberikan hak kepada Wajib Pajak untuk mendeklarasikan sendiri pajak terutang. Pajak yang dideklarasikan Wajib Pajak tersebut dianggap telah sesuai dengan peraturan perpajakan kecuali otoritas pajak dapat membuktikan bahwa pajak terutang tidak sesuai dengan ketentuan. Pembukuan atau pencatatan yang diwajibkan oleh Pasal 28 UU KUP menjadi acuan pemeriksa dalam melakukan

pengujian

melalui

penyandingan atau ekualisasi dengan bukti-bukti yang terkait dengan pembukuan atau dalam hal ini disebut dengan metode langsung. Namun dalam kondisi pembukuan tidak tersedia, tidak terdapat acuan awal bagi pemeriksa. Dalam kondisi demikian, melalui bukti yang ada pemeriksa tetap harus dapat membuktikan kebenaran dari pajak yang telah dilaporkan. Oleh karena itu, selain menggunakan metode langsung terkait pembukuan, pemeriksa harus dapat membuktikan pajak terutang melalui metode tidak langsung (Smith, 2015). Biber (2010) mendeskripsikan metode tidak langsung meliputi pengukuran utang pajak melalui analisis dari aktivitas keuangan Wajib Pajak menggunakan informasi dari berbagai sumber selain dari laporan keuangan Wajib Pajak. Penggunaan metode tidak langsung menjadi krusial karena pencatatan akuntansi untuk entitas yang kurang formal lebih terbatas dan kurang dapat diandalkan (Biber, 2010; OECD, 2006; Terkper, 2003). Apabila pencatatan akuntansi tersebut digunakan, maka hasil audit akan kurang presisi sehingga diperlukan metode tidak langsung dan data pihak ketiga (Terkper, 2003).

Dalam kondisi tidak tersedianya pembukuan atau pencatatan Pasal 14 ayat (5) Undang-Undang Nomor 7 Tahun 1983 sebagaimana telah diubah terakhir dengan Undang-Undang Nomor 36 Tahun 2008 tentang Pajak Penghasilan (UU PPh) juncto Pasal 1 PMK 15/2018 mengatur bahwa peredaran bruto Wajib Pajak dihitung dengan cara lain dan penghasilan neto dihitung menggunakan Norma Penghitungan Penghasilan Neto 
(NPPN). NPPN (deemed profit) adalah suatu rasio antara peredaran bruto dan penghasilan neto yang ditetapkan oleh otoritas pajak. Sementara cara lain adalah metode tidak langsung untuk mengukur peredaran bruto menggunakan delapan metode sebagaimana disebutkan dalam Pasal 2 PMK 15/2018. Istilah cara lain untuk menghitung peredaran bruto (cara lain) berdasarkan PMK 15/2018 merupakan terminologi dari UU PPh yang belum diatur definisinya dalam ketentuan perpajakan. Namun, nama dan definisi metode sebagaimana diatur dalam Pasal 2 PMK 15/2018 memiliki kesamaan dengan metode tidak langsung dalam penelitian Thuronyi (2004), OECD (2006), Biber (2010), dan Smith (2015).

Sejak diamanatkan dalam Pasal 14 ayat (5) UU PPh pada tahun 2008 hingga 2018, tidak terdapat Peraturan Menteri Keuangan yang mengatur tentang cara lain. Sebelum diundangkannya PMK 15/2018, Wajib Pajak yang tidak memperlihatkan atau melakukan pembukuan atau pencatatan atau tidak sepenuhnya melakukan pembukuan atau pencatatan, penghasilan netonya dihitung dengan menggunakan norma penghitungan penghasilan neto (NPPN). Namun, NPPN tidak dapat digunakan apabila peredaran bruto tidak diketahui karena informasi pembukuan atau pencatatan tidak tersedia. Hal itu dapat terjadi karena penghitungan penghasilan neto menggunakan NPPN dilakukan dengan mengalikan peredaran bruto dengan persentase NPPN. PMK 15/2018 memberi jawaban atas permasalahan tersebut dengan memberi kepastian hukum penghitungan peredaran bruto menggunakan cara lain. Dalam Pasal 2 PMK 15/2018 diatur bahwa WP yang tidak sepenuhnya menyelenggarakan pembukuan; atau tidak sepenuhnya memperlihatkan dan/atau meminjamkan pencatatan atau pembukuan atau bukti pendukungnya sehingga mengakibatkan peredaran bruto yang sebenarnya tidak diketahui, peredaran bruto Wajib Pajak yang bersangkutan dihitung dengan cara lain.

Meskipun memiliki peran yang krusial, PMK 15/2018 ini tidak serta-merta dapat diterapkan. Pasal 2 dan Pasal 3 PMK 15/2018 hanya mengatur nama dan ruang lingkup dari metode untuk menghitung peredaran bruto, sedangkan formula dan kondisi yang harus dipenuhi untuk menerapkan metode tersebut tidak diatur dalam PMK 15/2018. Berdasarkan Pasal 4 PMK 15/2018, ketentuan lebih lanjut mengenai tata cara penggunaan metode penghitungan peredaran bruto dengan cara lain diatur dengan Peraturan Direktur Jenderal Pajak (Perdirjen). Belum diterbitkannya Perdirjen peraturan pelaksanaan PMK 15/2018 ini menyebabkan tidak ada acuan bagi otoritas pajak mengenai penerapan cara lain. Oleh karena itu, peraturan pelaksanaan PMK 15/2018 mendesak untuk diundangkan.

Di samping perannya yang krusial, PMK 15/2018 ini juga memiliki pengaruh besar bagi masyarakat dan citra otoritas pajak. Pembangunan kepatuhan pajak sukarela harus menjadi prioritas mulai dari penyusunan peraturan sehingga sejalan dengan misi pertama Direktorat Jenderal Pajak (DJP) yaitu mengumpulkan 
penerimaan berdasarkan kepatuhan pajak sukarela yang tinggi dan penegakan hukum yang adil. Berdasarkan Slipery Slope Framework, keresahan masyarakat karena PMK 15/2018 harus dihindari dan kepercayaan terhadap otoritas pajak harus ditingkatkan untuk mencapai kepatuhan sukarela yang tinggi.

$$
\text { Penelitian }
$$$$
\text { ini }
$$

menggunakan

$$
\text { Slippery }
$$

akan

Framework untuk mendapatkan arah kebijakan yang tepat. Selanjutnya, berdasarkan arah kebijakan yang diturunkan dari Slippery Slope Framework, penulis akan menyajikan praktik internasional atas penggunaan metode tidak langsung dalam menghitung penghasilan berdasarkan Thuronyi (2004), OECD (2006), Biber (2010), dan Smith (2015). Praktik internasional tersebut akan menjadi acuan bagi formula dan kondisi yang diperlukan untuk menghitung penghasilan melalui metode tidak langsung. Signifikansi dari penelitian ini sangat jelas. Penelitian ini memberikan pandangan akademis mengenai penyusunan peraturan pelaksanaan PMK 15/2018 yang saat ini mendesak dibutuhkan. Selain itu, penelitian ini adalah penelitian pertama mengenai cara lain untuk menghitung peredaran bruto di Indonesia sehingga diharapkan dapat menjadi pembuka bagi penelitian selanjutnya.

\subsection{Perumusan Masalah}

Berdasarkan latar belakang sebagaimana diuraikan pada bagian 1.1 penulis merumuskan masalah utama yang harus dijawab dengan penelitian ini. Peraturan pelaksanaan PMK 15/2018 hanya mengatur definisi dari cara lain yang dibutuhkan untuk kepastian hukum baik bagi pemeriksa maupun Wajib Pajak dalam pemeriksaan. Selain itu, PMK 15/2018 yang menjadi sorotan Wajib Pajak mendorong pembuat peraturan untuk berhati-hati dalam menyusun peraturan pelaksanaan. Misi DJP mengumpulkan penerimaan berdasarkan kepatuhan pajak sukarela yang tinggi dan penegakan hukum yang adil harus diperhatikan dalam penyusunan peraturan. Dengan mempertimbangkan kebutuhan atas peraturan pelaksanaan dari PMK 15/2018 dan Misi DJP, penulis mendapatkan rumusan masalah sebagai berikut: "Bagaimana peraturan pelaksanaan cara lain untuk menghitung peredaran bruto yang mendukung kepatuhan sukarela."

\section{KERANGKA TEORITIS}

\subsection{Metode Cara Lain untuk Menghintung Peredaran Bruto}

Balter (1957) menjelaskan bahwa dalam sistem self assessment Wajib Pajak diberikan hak untuk mendeklarasikan utang pajaknya. Namun, hak tersebut diimbangi dengan kewajiban korelatif untuk mempertanggungjawabkan penilaiannya pada saat dilakukan pemeriksaan pajak. Jika otoritas pajak mendapati bahwa Wajib Pajak tidak memiliki metode akuntansi yang diterima umum atau pembukuan Wajib Pajak tidak 
mengumpulkan penerimaan berdasarkan kepatuhan pajak sukarela yang tinggi dan penegakan hukum yang adil. Kirchler et al. (2008) memperkenalkan Slipery Slope Framework yang merupakan rerangka untuk menjelaskan dampak dari kepercayaan terhadap otoritas dan kekuatan otoritas terhadap dua jenis kepatuhan pajak yaitu kepatuhan sukarela dan kepatuhan yang dipaksakan. Kirchler et al. (2008) menjelaskan bahwa kekuatan otoritas adalah persepsi Wajib Pajak bahwa otoritas pajak dapat mendeteksi penghindaran pajak, misalnya dengan melakukan pemeriksaan pajak yang sering dan mendalam dan kemampuan otoritas pajak dalam menghukum penghindaran pajak misalnya dengan memberikan denda yang besar kepada Wajib Pajak.

Kepercayaan terhadap otoritas dijelaskan sebagai opini dari individu maupun kelompok sosial bahwa otoritas pajak bertindak secara bijak dan dan bekerja dengan baik untuk kebaikan bersama. Dalam Slippery Slope Framework, diasumsikan bahwa kepatuhan pajak dapat dicapai melalui peningkatan kekuatan otoritas dan kepercayaan, tetapi menghasilkan jenis kepatuhan yang berbeda. Peningkatan kekuatan otoritas cenderung menghasilkan kepatuhan yang dipaksakan sedangkan peningkatan kepercayaan terhadap otoritas cenderung menghasilan kepatuhan sukarela sebagaimana digambarkan pada Grafik 1.

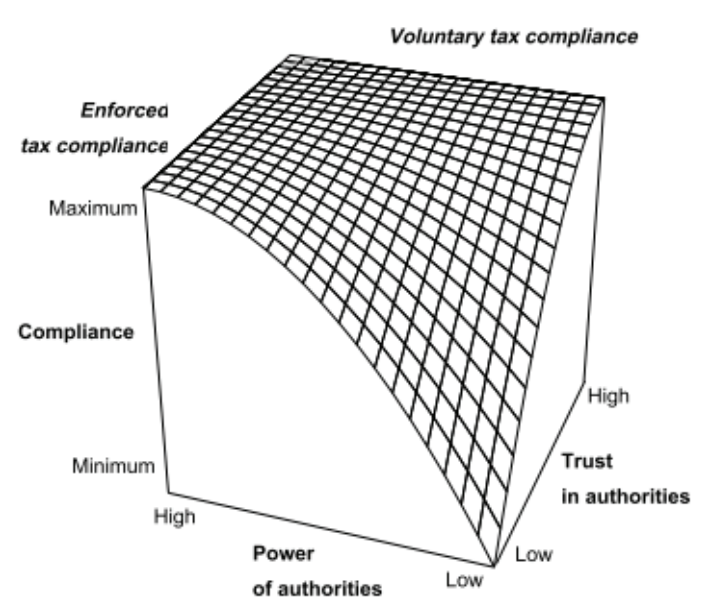

Grafik 1 Slippery Slope Framework

Sumber: Enforced versus voluntary tax compliance: The "slippery slope" framework.

(Kirchler et al., 2008)

\subsection{Membangun kepatuhan sukarela melalui peraturan pelaksanaan cara lain untuk menghitung peredaran bruto}

Apabila pemeriksaan pajak erat kaitannya dengan kekuatan otoritas, bagaimana membangun kepatuhan sukarela melalui peraturan mengenai pemeriksaan pajak? Untuk menjawab pertanyaan itu, Kirchler et al. (2008) menjelaskan bahwa kekuatan otoritas dan kepercayaan terhadap otoritas dapat saling mempengaruhi. Benar adanya bahwa naiknya kekuatan otoritas cenderung menurunkan kepercayaan terhadap otoritas apabila otoritas pajak meningkatkan audit yang dapat diinterpretasikan oleh Wajib Pajak sebagai sinyal bahwa otoritas mempertahankan sikap "cops and robbers" dan ketidakpercayaan terhadap kejujuran Wajib Pajak. Cialdini (1996) dan Frey (2003) dalam Kirchler et al. (2008) berpendapat bahwa pengawasan 
dipandang sebagai tanda dari ketidakpercayaan yang dapat mengurangi kepercayaan terhadap otoritas. Kemungkinan ini terjadi apabila pemeriksaan pajak dilakukan sangat sering dan dengan gaya inquisitorial yaitu otoritas pajak bertindak sebagai penegak hukum yang juga secara aktif ikut melakukan pengujian lewat pemeriksaan.

Di sisi lain, pemeriksaan pajak juga dapat meningkatkan kepercayaan terhadap otoritas. Jika otoritas pajak dipersepsikan bahwa lebih efisien dalam mendeteksi kecurangan pajak dan menegakkan keadilan maka kepercayaan dari Wajib Pajak jujur terhadap otoritas akan meningkat (Kirchler et al., 2008). Hal ini sesuai dengan konsep keadilan retributif dalam penelitian (Wenzel, 2003). Bergman (2003) juga berpendapat bahwa sanksi yang kredibel berdasarkan kekuatan terlegitimasi adalah alat yang efektif untuk meningkatkan kepercayaan terhadap otoritas dan meningkatkan kepatuhan pajak. Hal ini berkaitan dengan pengaturan mengenai penggunaan metode tidak langsung dalam menghitung penghasilan akan berdampak langsung terhadap persepsi masyarakat tentang pemeriksaan pajak.

Agar pengaturan tersebut sesuai dengan Misi DJP, maka arah kebijakan berdasarkan kerangka teoritis sesuai penelitian Kirchler et al.(2008) adalah sebagai berikut:

\section{1. peraturan yang handal}

Peraturan pelaksanaan cara lain harus handal mendeteksi kecurangan pajak.
Peraturan harus memiliki dasar hukum yang kuat sehingga dapat diandalkan untuk menegakkan hukum terhadap kecurangan pajak.

\section{2. metode yang objektif}

Otoritas pajak harus dipersepsikan dapat menjunjung tinggi rasa keadilan agar kepercayaan terhadap otoritas meningkat. Untuk dapat dipersepsikan adil, maka diperlukan formula dan kondisi pemilihan metode yang bebas dari kesalahan logika, ambiguitas, dan subjektivitas otoritas pajak. Contohnya penggunaan patokan (benchmark), seperti menentukan penghasilan berdasarkan pertumbuhan ekonomi nasional, dapat menyebabkan hasil dengan deviasi yang besar dari penghasilan yang sebenarnya diterima Wajib Pajak.

3. sanksi kredibel berdasarkan kekuatan terlegitimasi

Sanksi kredibel berdasarkan kekuatan terlegitimasi adalah alat yang efektif untuk meningkatkan kepercayaan terhadap otoritas. Sanksi yang ditetapkan berdasarkan peraturan yang tidak terdapat dalam hierarki peraturan perundangan dapat menimbulkan rasa ketidakadilan. Oleh karena itu, pemberian sanksi harus dilakukan berdasarkan peraturan yang kredibel. 


\section{METODOLOGI PENELITIAN}

Penelitian ini menggunakan metode penelitian hukum normatif yang dilakukan dengan cara meneliti bahan kepustakaan (Effendi, 2016). Menurut Effendi (2016), penelitian hukum normatif memerlukan pendekatan yang sesuai untuk hasil yang optimal antara lain, pendekatan hukum (statute approach) yang menekankan sistematika dan koherensi dari suatu peraturan, pendekatan konsep (conceptual approach) yang menekankan pembahasan suatu konsep, dan pendekatan perbandingan (comparative approach) yang membangun pengetahuan umum mengenai hukum positif dengan membandingkan hukum dari negara yang berbeda. Metode penelitian hukum empiris, yaitu metode penelitian yang dilakukan berdasarkan data primer (Effendi, 2016), tidak digunakan dalam penelitian ini karena peraturan mengenai cara lain belum sepenuhnya dapat diterapkan. Hal itu menyebabkan tidak adanya data primer terkait penerapan peraturan ini.

\section{Pendekatan Hukum}

(analisis koherensi dan sistematika hukum)

Rumusan Masalah

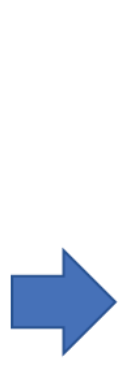

\section{Pendekatan Konsep}

(analisis konsep yang melandasi hukum)

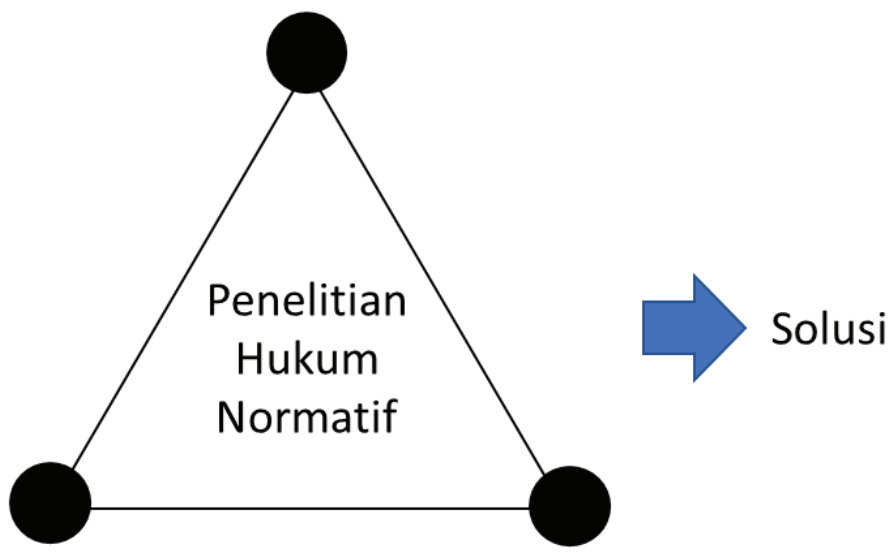

Pendekatan Perbandingan

(pembandingan dengan negara/ yuridiksi lain)

Grafik 2 Metode Penelitian Hukum Normatif

Sumber: Metode Penelitian Hukum : Normatif dan Empiris (Effendy, 2016)

Dalam penelitian ini pendekatan hukum dilakukan dengan membahas koherensi dan sistematika peraturan perpajakan yang mengatur mengenai cara lain. Meskipun tata cara penggunaan metode cara lain belum diatur dalam PMK 15/2018, pendekatan hukum tetap tetap dilakukan untuk menganalisis koherensi dan sistematika peraturan pelaksanaan cara lain untuk menghitung peredaran bruto. Pendekatan konsep dilakukan dengan mengkaji literatur tentang konsep kepatuhan sukarela berdasarkan Slippery Slope Framework. 
Pendekatan perbandingan dilakukan dengan mengkaji literatur tentang praktik internasional atas penggunaan cara lain. Kerangka teoritis penelitian ini disajikan pada Grafik 2.

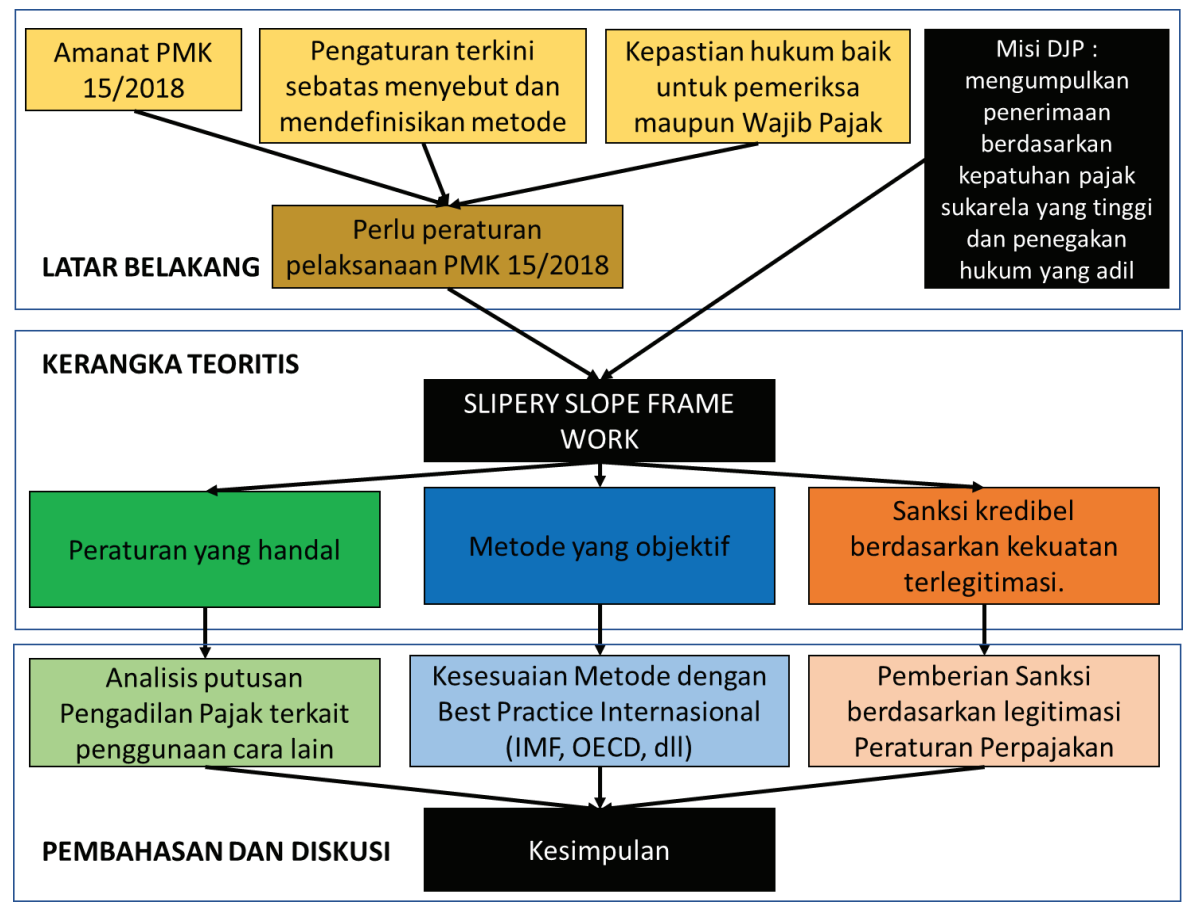

Grafik 2. Kerangka Pemikiran

\section{HASIL DAN PEMBAHASAN}

\subsection{Peraturan yang handal}

Sebelum diterbitkannya PMK 15/2018, metode tidak langsung sebenarnya telah dikenal dalam SE-65/PJ/2013 Tentang Pedoman Penggunaan Metode dan Teknik Pemeriksaan (SE-65/PJ/2013). Terdapat kesamaan nama metode cara lain dalam PMK 15/2018 dengan metode tidak langsung dalam lampiran SE-65/PJ/2013. Namun, pengaturan tersebut merupakan pedoman internal karena tidak diamanatkan dalam PMK 17/2013 tentang Tata Cara Pemeriksaan sebagaimana telah diubah dengan PMK 184/2015 dan aturan pelaksanaan lainnya sehingga tidak dapat dijadikan dasar hukum yang mengikat.

Metode tidak langsung pernah diatur dalam Perdirjen Nomor PER-04/2012 tentang Pedoman Penggunaan Metode dan Teknik Pemeriksaan untuk Menguji Kepatuhan Pemenuhan Kewajiban Perpajakan (PER-04/2012) sebagai amanat dari 
Perdirjen Nomor PER-9/2010 tentang Standar Pemeriksaan (PER-9/2014). Namun PER-04/2012 ini dicabut dengan PER-07/2014 selaras dengan PER-23/2013 tentang Standar Pemeriksaan sebagai pengganti dari PER-9/2010 tidak mengamanatkan kembali adanya Perdirjen mengenai metode dan teknik pemeriksaan.

Kedudukan peraturan mengenai metode tidak langsung yang hanya merupakan pedoman internal menyebabkan kekalahan pihak DJP dalam pembuktian di pengadilan pajak. Dari 455 putusan sengketa terkait PPh Badan tahun 2017 yang dilihat dari Putusan Pengadilan Pajak, terdapat 160 koreksi yang didasari dengan ekualisasi peredaran usaha dengan menggunakan metode tidak langsung.

Atas koreksi tersebut, oleh majelis hakim pada saat banding dilaksanakan melalui pembuktian menggunakan metode uji bukti dimana pemohon banding dan terbanding menghitung ulang sesuai bukti-bukti yang dapat dipertimbangkan di pengadilan. Grafik 3 menyajikan hasil putusan pengadilan pajak tentang 160 koreksi ekualisasi peredaran usaha dengan metode tidak langsung pada tahun 2017.

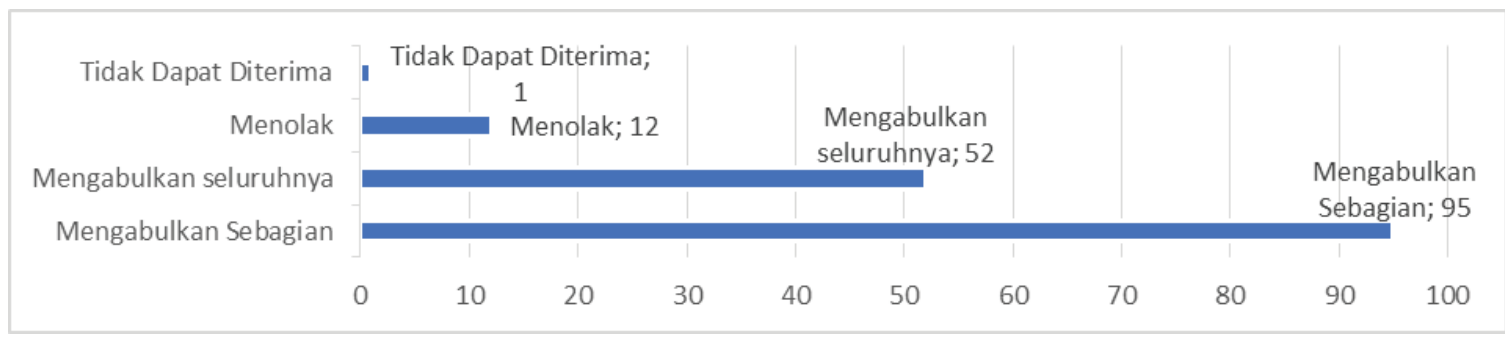

Grafik 3 Putusan Pengadilan Pajak terkait penggunaan metode tidak langsung Sumber : Daftar Putusan Pengadilan Pajak

Perlu dipahami berdasarkan Pasal 12 ayat (3) Undang-Undang Nomor 6 tahun 1983 tentang Ketentuan Umum dan Tata Perpajakan sebagaimana telah diubah dengan Undang-Undang Nomor 16 tahun 2009 (UU KUP) meskipun tidak menggunakan bukti langsung, otoritas pajak tetap harus membuktikan penghasilan Wajib Pajak. Otoritas pajak tidak dapat secara subjektif menggunakan estimasi atau asumsi seperti dalam akuntansi misalnya estimasi ketertagihan piutang atau masa manfaat aset tetap.
Metode cara lain yang baik seharusnya memberikan dasar yang kuat bagi pemeriksa untuk dapat membuktikan penghasilan Wajib Pajak yang sebenarnya (OECD, 2006). 


\subsection{Metode yang objektif}

4.2.1. Formula dalam metode cara lain

Pasal 2 PMK 15/2018 mengatur delapan metode cara lain untuk menghitung peredaran bruto. Namun, formula dari delapan metode tersebut belum diatur dalam PMK-15/2018.

Kedelapan metode cara lain tersebut meliputi metode:
a. transaksi tunai dan nontunai;
b. sumber dan penggunaan dana;
c. satuan dan/atau volume;
d. penghitungan biaya hidup;
e. pertambahan kekayaan bersih;

f. berdasarkan Surat Pemberitahuan atau hasil pemeriksaan tahun pajak sebelumnya;

g. proyeksi nilai ekonomi; dan/atau

h. penghitungan rasio.

Berdasarkan kesamaan nama metode tidak langsung dalam SE-65/PJ/2013 dan Pasal 2 huruf a s.d. e PMK 15/2018 penulis beranggapan bahwa metode dalam PMK 15/2018 akan mengadopsi metode tidak langsung dalam SE-65/P$\mathrm{J} / 2013$. Oleh karena itu, pembahasan dalam penelitian ini akan mengacu formula sebagaimana diatur dalam SE-65/PJ/2013. Berdasarkan Biber (2010), OECD (2006) dan Smith (2015) metode sebagaimana diatur dalam Pasal 2 huruf a, b, c, dan e PMK 15/2018 telah sesuai dengan praktik internasional sehingga keandalannya sudah teruji. Namun, metode dalam Pasal 2 huruf $d, f, g$, dan $h$ yaitu, penghitungan biaya hidup, berdasarkan Surat Pemberitahuan (SPT) atau hasil pemeriksaan tahun pajak sebelumnya, proyeksi nilai ekonomi, dan rasio tidak dapat ditemukan dalam penelitian tersebut.

Meskipun telah menjadi praktik internasional, metode cara lain tidak dapat langsung diterapkan karena penggunaan NPPN. Pasal 14 ayat (5) UU PPh mengatur bahwa peredaran Wajib Pajak dihitung dengan cara lain dan penghasilan neto dihitung dengan NPPN. Berdasarkan Biber (2010) dan OECD (2006) hasil penghitungan metode cara lain akan langsung dianggap sebagai penghasilan neto dan Wajib Pajak dibebani kewajiban untuk menyerahkan bukti transaksi untuk diakui sebagai biaya. Perbedaan ini menyebabkan terdapat metode dalam SE-65/PJ/2013 yang perlu disesuaikan dengan praktik internasional dalam OECD (2006), Biber (2010), dan Smith (2015). Tabel 1 dalam Lampiran menyajikan ringkasan rekomendasi kebijakan metode cara lain.

4.2.1.1 Metode tunai dan non tunai dan volume usaha

Metode tunai dan non tunai dan volume usaha adalah metode yang tidak memerlukan penyesuaian untuk dituangkan dalam peraturan pelaksanaan PMK 15/2018. Hasil dari kedua metode tersebut adalah peredaran bruto sehingga dapat langsung dikali dengan NPPN untuk mendapatkan penghasilan neto. Namun untuk memberikan kepastian hukum metode kas perlu diberikan kondisi pemilihan metode yang tegas. Berdasarkan OECD (2006) kondisi tersebut adalah terdapat data buku kas dan/atau buku bank yang lengkap (diketahui saldo awal, saldo akhir, total pengeluaran secara utuh, tidak ada 
informasi yang terpotong), penghasilan secara kredit tidak lebih dari 50\% dan Wajib Pajak melakukan setoran secara periodik ke bank yang berasal dari income-producing activity.

\subsubsection{Metode sumber dan} penggunaan dana dan pertambahan kekayaan bersih

Metode ini tidak dapat digunakan dalam menghitung peredaran bruto karena metode ini menghasilkan penghasilan neto, sedangkan dalam PMK-15/2018, hasil perhitungan akan dihitung kembali dengan NPPN sehingga menghasilkan penghasilan neto.
Hal ini disebabkan oleh pendekatan aktiva-hutang (neraca) yang digunakan dalam metode tersebut. Berbeda dengan metode lainnya yang menggunakan pendekatan penghasilan-biaya. Dalam pendekatan neraca, selisih dari modal periode pengamatan dengan periode sebelumnya dalam persamaan akuntansi akan selalu menghasilkan penghasilan neto. Jika metode ini diadopsi langsung dalam peraturan pelaksanaan PMK 15/2018 maka akan terjadi kesalahan logika karena penghasilan neto sudah ditemukan sebelum mengenakan NPPN. Simulasi penghitungan metode pendekatan neraca disajikan dengan Gambar 1.

\begin{tabular}{|c|c|c|c|c|c|c|}
\hline $\operatorname{ASET}(t)$ & UTANG $(\mathrm{t})$ & $A L(t)$ & Modal (t) & 100 & Pendapatan $(t)$ & 125 \\
\hline 150 & 50 & 100 & Modal (t-1) & 50 & Beban (t) & 75 \\
\hline $\begin{array}{l}\text { SET }(t-1) \\
100\end{array}$ & $\begin{array}{c}\text { UTANG }(\mathrm{t} \\
50\end{array}$ & $\begin{array}{l}\text { MODAL }(t-1) \\
50\end{array}$ & Penghasilan (t) & 50 & Penghasilan (t) & 50 \\
\hline
\end{tabular}

Selisih modal dengan periode sebelumnya (diluar transaksi dengan pemilik dan kreditor) selalu menghasilkan penghasilan neto.

Gambar 1. Simulasi metode tidak langsung pendekatan neraca

Terdapat dua alternatif atas masalah tersebut, yaitu mengenakan NPPN $100 \%$ atau menambahkan hasil penghitungan dengan biaya. Dengan mengenakan NPPN sebesar 100\% sama saja dengan tidak mengenakan NPPN sehingga penghasilan neto ditetapkan sebesar hasil penggunaan kedua metode ini. Namun, tarif NPPN sebesar 100\% dapat memberikan sinyal yang salah kepada Wajib Pajak karena dinilai otoritas pajak memberikan tarif yang tinggi. Alternatif dari pengenaan NPPN 100\% adalah dengan menambahkan biaya ke dalam formula. Dengan menambahkan biaya maka penghasilan

\subsubsection{Metode biaya hidup}

Mengacu pada SE-65/PJ/2013, dalam metode penghitungan biaya hidup diasumsikan bahwa Wajib Pajak menggunakan penghasilannya untuk membayar biaya hidup berupa transportasi, pendidikan, kesehatan, dan lain sebagainya. Hal ini menegaskan bahwa metode ini hanya relevan dilakukan pada Wajib Pajak Orang Pribadi non pengusaha. Metode tidak akurat ketika digunakan pada Wajib Pajak Orang Pribadi pengusaha atau Wajib Pajak Badan karena terdapat biaya untuk menjalankan usaha. 
Asumsi beban sama dengan peredaran bruto sama artinya dengan menganggap margin keuntungan sebesar nol. Akibatnya, peredaran bruto hasil metode ini untuk Wajib Pajak dalam kondisi untung akan lebih kecil dari seharusnya. Sebaliknya, dalam kondisi rugi maka peredaran bruto akan ditetapkan lebih besar dari seharusnya. Namun, kondisi untung dan rugi tidak dibutuhkan untuk Wajib Pajak Orang Pribadi non pengusaha karena biaya hidup tidak diperhitungkan dalam penghitungan PPh. Oleh karena itu, penulis menyarankan agar penerapan metode ini hanya dilakukan pada Wajib Pajak Orang Pribadi non pengusaha.

\subsubsection{Metode berdasarkan SPT dan hasil pemeriksaan tahun pajak sebelumnya}

Metode berdasarkan surat pemberitahuan dan hasil pemeriksaan tahun pajak sebelumnya merupakan metode yang baru dikenal dalam peraturan pajak dan tidak ditemukan praktik internasional atas metode ini. Penggunaan yang telah lampau dapat menimbulkan isu relevansi karena kondisi Wajib Pajak saat diperiksa kemungkinan besar berbeda dengan kondisi dalam Surat Pemberitahuan (SPT) atau hasil pemeriksaan tahun pajak sebelumnya. Agar metode ini bebas dari subjektivitas, maka perlu diatur penggunaan metode pertumbuhan untuk menyesuaikan antara data yang telah lampau dengan data saat pemeriksaan.
Sebagai alternatif, otoritas pajak dapat menggunakan metode pertumbuhan internal Wajib Pajak dari beberapa tahun sebelumnya atau dengan pertumbuhan sektoral Wajib Pajak sejenis. Penggunaan pertumbuhan sektoral mudah digunakan, namun dapat menyebabkan bias karena data sektoral merupakan data agregat. Penggunaan data agregat menjadi tidak objektif ketika terdapat deviasi yang besar antara data agregat dengan pertumbuhan Wajib Pajak. Penggunaan pertumbuhan internal Wajib Pajak menjadi tidak akurat ketika terjadi penurunan atau kenaikan tajam performa Wajib Pajak. Untuk menjaga objektivitas, diperlukan rentang waktu yang panjang sehingga data agregat lebih akurat. Disarankan agar dalam pemilihan metode, diatur bahwa metode ini hanya dapat dilakukan jika terdapat dara berurutan selama beberapa tahun.

\subsubsection{Metode proyeksi nilai ekonomi}

Jika metode ini dianalogikan dengan proyeksi keekonomian proyek dalam manajemen keuangan, maka metode akan menjadi asumtif. Terdapat perbedaan mendasar dalam fungsi proyeksi dalam manajemen keuangan dengan pembuktian secara tidak langsung menggunakan cara lain. Proyeksi keekonomian bertujuan untuk menganalisa proyek-proyek dan menentuan mana saja yang dimasukkan ke dalam anggaran modal (Titman, S., Keown, A. J., \& Martin, 2011). (Titman, S., Keown, A. J., \& Martin, 2011). Jadi, dalam manajemen keuangan arus kas bebas diestimasi oleh manajemen untuk kemudian dianalisa nilai ekonominya. 
Berbeda dengan cara lain, justru arus kas bebas yang menentukan peredaran bruto lah yang tidak diketahui. Oleh karena itu, analogi proyeksi keekonomian dalam manajemen keuangan tidak tepat untuk diadopsi dalam peraturan pelaksanaan PMK 15/2018.

Sebagai alternatif, penulis menyarankan agar metode ini mengadopsi metode mark up yang belum diadopsi dalam SE-65/PJ/2013, namun sudah ada praktik internasionalnya. Metode mark up pada intinya adalah metode untuk memproyeksikan peredaran bruto berdasarkan perkalian antara harga pokok penjualan dengan persentase mark up (Biber, 2010). Persentase mark up diperoleh dari perbandingan antara harga jual per unit dengan biaya per unit. Metode ini lebih efektif dilakukan daripada metode volume usaha jika jumlah barang secara pasti tidak diketahui. Namun, nilai harga pokok penjualan secara total diketahui. Hasil dari metode mark up adalah peredaran bruto sehingga dapat langsung diadopsi dalam peraturan pelaksanaan PMK 15/2018 tanpa modifikasi.

\subsubsection{Metode Rasio}

Sebagaimana telah diatur dalam Pasal 14 ayat (5) UU PPh, apabila pada saat diperiksa Wajib Pajak memenuhi syarat untuk dihitung penghasilannya menggunakan metode tidak langsung, maka pemeriksaan wajib dilakukan dengan ketentuan PMK 15/2018. Jika tidak ada satupun kondisi yang dapat dipenuhi untuk menggunakan suatu metode, maka akan terdapat ketidakpastian hukum terhadap penghitungan penghasilan Wajib Pajak karena penghasilannya wajib dihitung dengan cara lain. Namun, tidak ada cara lain yang memenuhi syarat untuk digunakan. Oleh karena itu, perlu dipastikan bahwa paling tidak terdapat satu metode dalam PMK 15/2018 yang dapat digunakan meskipun bukti tidak langsung yang tersedia sangat terbatas.

Untuk memastikan bahwa minimal terdapat satu metode cara lain yang dapat digunakan, perlu diatur metode yang fleksibel. Ruang lingkup sebagaimana diatur dalam Pasal 3 ayat (8) PMK 15/2018 hanya mengatur bahwa metode ini dilakukan berdasarkan persentase atau rasio pembanding. Secara implisit, SE-65/PJ/2013 mengatur bahwa peredaran bruto dengan metode ini didapat dari basis data dikali dengan rasio pembanding. Meskipun tetap mempertimbangkan fleksibilitas, namun metode rasio harus tetap memenuhi syarat bebas dari estimasi dan ambiguitas. Alih-alih membebaskan dari mana basis data dan rasio diperoleh, penulis menyarankan agar terdapat rasio keuangan yang secara rutin ditetapkan oleh otoritas pajak. Penetapan acuan atau benchmark sebagaimana diterapkan oleh otoritas pajak Australia, New Zealand, Jerman, dan Amerika Serikat sebagaimana dituangkan dalam OECD (2006) dapat diadopsi di Indonesia.

\subsubsection{Kriteria pemilihan metode}

Tidak kalah pentingnya dengan formula yang objektif, pemilihan metode juga harus objektif. Selain untuk melindungi 
Wajib Pajak dari subjektivitas pemeriksa, peraturan juga perlu memperkuat posisi otoritas pajak di pengadilan pajak. Oleh karena itu, pemilihan metode harus memiliki dasar kriteria yang jelas. Selain dengan kriteria, pemilihan metode dapat dilakukan secara sekuensial. Namun, metode sekuensial akan membutuhkan banyak waktu untuk dilakukan dan tidak efisien karena pemeriksa harus melalui sserangkaian metode untuk menuju metode yang optimal. Cara sekuensial memungkinkan pemeriksa untuk terpaksa menggunakan metode yang tidak optimal karena suatu metode tidak dapat ditolak penggunaannya.

Penulis menyarankan agar pemilihan metode yang ideal dilakukan secara sekuensial untuk dua bagian besar yaitu metode yang sesuai dengan praktik internasional dan dilanjutkan dengan metode yang tidak terdapat dalam praktik internasional. Namun, pemilihan metode dalam bagian besar tersebut dilakukan sesuai kriteria. Diharapkan metode sekuensial dapat mengurangi penggunaan metode yang tidak sesuai dengan praktik internasional. Selain itu, dengan menggunakan kriteria, maka metode tidak langsung sesuai praktik internasional dapat secara efisien digunakan.

\subsection{Sanksi yang kredibel berdasarkan peraturan yang terlegitimasi}

Istilah cara lain untuk menghitung peredaran bruto baru dimunculkan pada UU PPh Tahun 2008. Pada UU PPh sebelumnya, mulai dengan UU PPh tahun 1983 sampai dengan tahun 2000 tidak ditemui cara lain untuk menghitung peredaran bruto. Sebelum tahun 2008, Wajib Pajak yang tidak atau tidak sepenuhnya melakukan atau memperlihatkan pembukuan atau pencatatan, penghasilan netonya dihitung dengan NPPN. Hingga tahun 2015, pengaturan yang ada kurang lebih masih sama sebagaimana diatur dalam PER-17/PJ/2015 tentang Norma Penghitungan Penghasilan Neto (PER-17/PJ/2015) yaitu penghasilan neto dihitung menggunakan NPPN. Namun, penggunaan NPPN dalam kondisi tidak ada pembukuan menyebabkan ketidakjelasan dalam penerapannya. Pasalnya, untuk dapat menggunakan NPPN, diperlukan peredaran bruto terlebih dahulu sebagai basis perkalian. Akan tetapi, dengan tidak adanya pembukuan, maka peredaran bruto menjadi tidak diketahui sehingga penghitungan penghasilan neto tidak dapat dilakukan.

Penggunaan cara lain mengubah persepsi bahwa metode tidak langsung digunakan untuk memberikan keyakinan yang memadai mengenai penghasilan Wajib Pajak, jadi bukan untuk menghukum. Hal ini diperkuat juga dengan dihapusnya sanksi kenaikan 50\% bagi Wajib Pajak yang tidak melakukan pembukuan dalam KEP-536/PJ/2000 tentang Norma Penghitungan 
Penghasilan Neto bagi Wajib Pajak yang Dapat Menghitung Penghasilan Neto Dengan Menggunakan Norma Penghitungan.PER-17/PJ/2015 mengembalikan ranah pemberian saksi sesuai koridor yang seharusnya yaitu melalui UU KUP. Langkah ini telah sesuai dengan arah kebijakan pemberian sanksi yang kredibel sesuai Slippery Slope Framework.

\section{KESIMPULAN}

Peraturan pelaksanaan cara lain untuk menghitung peredaran bruto yang mendukung kepatuhan sukarela rela harus memenuhi syarat andal, objektif, dan dapat diberikan sanksi secara kredibel berdasarkan kekuatan terlegitimasi. Berdasarkan struktur pendelegasian peraturan perundangan peraturan, pelaksanaan PMK 15/2018 memiliki dasar yang kuat sehingga dipastikan andal untuk digunakan sebagai dasar hukum koreksi. Untuk mencapai metode yang objektif, diperlukan modifikasi metode dalam SE-65/PJ/2013 dan praktik internasional dalam OECD (2006), Biber (2010), dan Smith (2015). Sanksi yang kredibel harus diberikan berdasarkan peraturan perpajakan yang memiliki legitimasi untuk mengatur sanksi perpajakan yaitu UU KUP bukan melalui NPPN.

\section{IMPLIKASI DAN KETERBATASAN}

Penelitian ini diharapkan dapat memberikan pandangan akademis dalam pembuatan kebijakan peraturan pelaksanaan PMK 15/2018 dan RUU PPh sehingga dapat menumbuhkan kepatuhan sukarela dan penegakan hukum yang adil sesuai dengan misi DJP. Karena ruang lingkup penelitian ini hanya membahas mengenai peraturan pelaksanaan PMK 15/2018, diperlukan penelitian lebih lanjut agar kebijakan perpajakan menjadi paripurna. Penulis mendapati bahwa penelitian ini masih perlu ditingkatkan terutama dalam rangka penyempurnaan sanksi yang ideal atas tidak tersedianya pembukuan atau pencatatan dalam UU KUP. Hukuman yang diberikan kepada Wajib Pajak yang tidak menyelenggarakan pembukuan dikenakan secara kumulatif atas sanksi administratif pada pasal 13 ayat (3) UU KUP dan kenaikan pasal 13A UU KUP atau pidana Pasal 39 UU KUP. Hal ini dimungkinkan karena UU KUP menghiraukan doktrin hukum yang berlaku umum yaitu ne bis in idem. Tidak dipakainya doktrin ne bis in idem pada penerapan hukuman atas tidak tersedianya pembukuan membuat ketentuan ini tidak sesuai dengan asas hukum yang berlaku umum. Penelitian selanjutnya juga diharapkan dapat mengkaji evaluasi dan dampak dari kebijakan peraturan pelaksanaan PMK 15/2018. Hasil penelitian yang ditemukan diharapkan lebih komprehensif sehingga dapat memberikan masukan bagi pemangku kepentingan dengan lebih optimal. Peraturan ibarat hulu yang menentukan jenis kepatuhan yang akan timbul di masyarakat. Agar kepatuhan sukarela dapat dengan mudah dibangun, peneliti menyarankan agar pengembangan kebijakan penyusunan peraturan didasari dari konsep kepatuhan sukarela. Penelitian ini merupakan hasil pemikiran pribadi penulis dan tidak merepresentasikan organisasi DJP. 


\section{DAFTAR PUSTAKA}

[1] Balter, H. G. (1957). Problems Relating To Taxpayer ' s Obligation To Retain Adequate Books and Records for Federal Income Tax Purposes. Marquette Law Review, 41(2), 107-120.

[2] Bergman, M. S. (2003). Tax reforms and tax compliance: The divergent paths of Chile and Argentina. Journal of Latin American Studies, 35(3), 593-624.

[3] Biber, E. (2010). Revenue Administration: Taxpayer Audit-Use of Indirect Methods. Technical Notes and Manuals. Washington DC.

[4] Braithwaite, V. (2002). Dancing With Tax Authorities: Motivational Postures and Non-Compliant Actions. In Taxing Democracy. Aldershot: Ashgate Publishing Ltd.

[5] Cialdini, R. B. (1996). The triple tumor structure of organizational behavior. New York: Sage.

[6] Direktorat Jenderal Pajak. (2000). Keputusan Direktur Jenderal Pajak Nomor KEP-536/PJ/2000 Norma Penghitungan Penghasilan Neto Bagi Wajib Pajak yang Dapat Menghitung Penghasilan Neto dengan Menggunakan Norma Penghitungan.

[7] Direktorat Jenderal Pajak. (2010). Peraturan Direktur Jenderal Pajak Nomor PER-9/2010 Standar Pemeriksaan untuk Menguji Kepatuhan Pemenuhan Kewajiban Perpajakan.

[8] Direktorat Jenderal Pajak. (2012). Peraturan Direktur Jenderal Pajak Nomor PER-04/PJ/2012 Pedoman Penggunaan Metode Dan Teknik Pemeriksaan untuk Menguji Kepatuhan Pemenuhan Kewajiban Perpajakan.

[9] Direktorat Jenderal Pajak. (2013). Peraturan Direktur Jenderal Pajak Nomor PER-23/PJ/2013 Tentang Standar Pemeriksaan.

[10] Direktorat Jenderal Pajak. (2014). Peraturan Direktur Jenderal Pajak Nomor PER-07/PJ/2014 Pencabutan Peraturan Direktur Jenderal Pajak Nomor PER-04/PJ/2012 Tentang Pedoman Penggunaan Metode dan Teknik Pemeriksaan untuk Menguji Kepatuhan Pemenuhan Kewajiban Perpajakan.
[11] Direktorat Jenderal Pajak. (2015). Peraturan Direktur Jenderal Pajak Nomor PER-17/PJ/2015 Tentang Norma Penghitungan Penghasilan Neto.

[12] Effendi, J. (2016). Metode Penelitian Hukum Normatif dan Empiris. Depok: Prenadamedia Group.

[13] Frey, B. S. (2003). Deterrence and tax morale in the European Union. European Review, 11(3), 385-406.

[14] Kementerian Keuangan Republik Indonesia. (2015). Peraturan Menteri Keuangan Nomor 17/PMK.03/2013 Tentang Tata Cara Pemeriksaan sebagaimana diubah dengan Peraturan Menteri Keuangan Nomor 184/PMK.03/2015. Kementerian Keuangan Republik Indonesia. (2018). Peraturan Menteri Keuangan Nomor 15/PMK.03/2018 Tentang Cara Lain untuk Menghitung Peredaran Bruto.

[15] Kirchler, E., Hoelzl, E., \& Wahl, I. (2008). Enforced versus voluntary tax compliance: The "' slippery slope "' framework. Journal of Economic Psychology, 29, 210-225.

[16] OECD. (2006). Strengthening Tax audit Capabilities: Innovative Approaches to Improve the Efficiency and Effectiveness of Indirect Income Measurement Methods. Washington DC.

[17] Prastowo, Y. (2018). Benarkah PMK-15 Bikin Resah? diakses pada 21 November 2018, dari https://cita.or.id/opini/artikel/benarkah-pmk-15-bikin-resah/

[18] Republik Indonesia. (2008). Undang-Undang Nomor 7 Tahun 1983 Tentang Pajak Penghasilan sebagaimana telah dubah terakhir dengan Undang-Undang Nomor 36 Tahun 2008.

[19] Republik Indonesia. (2009). Undang Undang Nomor 6 Tahun 1983 Tentang Ketentuan Umum dan Tata Cara Perpajakan sebagaimana telah diubah terakhir dengan Undang-Undang Nomor 16 Tahun 2009

[20] Smith, E. (2015). Defending a Cash Business Taxpayer in an Indirect Method Case. The CPA Journal, 85(11), 56-57.

[21] Terkper, S. (2003). Managing Small and Medium-Size Taxpayers in Developing Economies. Tax Notes International, (January), 211-234. 
Furqon Nurhandono, Darius H., Tri K. / Kajian Akademis Peraturan Pelaksanaan... (2020) 149-166

[22] Thuronyi, V. (2004). Presumptive Taxation of the Hard-to-Tax. In Taxing The Hard to Tax Lessons from Theory and Practice (Vol. 8555, pp. 101-120). West Yorkshire: Emerald Group Publishing.

[23] Titman, S., Keown, A. J., \& Martin, J. D. (2011). Financial management: Principles and applications (Volume 11). Boston: Prentice Hall.

[24] Wenzel, M. (2003). Tax compliance and the psychology of justice: Mapping the field. In Taxing Democracy (pp. 41-49). Aldershot: Ashgate Publishing Ltd. 


\section{LAMPIRAN}

\section{Tabel 1 Perbandingan Pengaturan terkini dengan Rekomendasi Kebijakan}

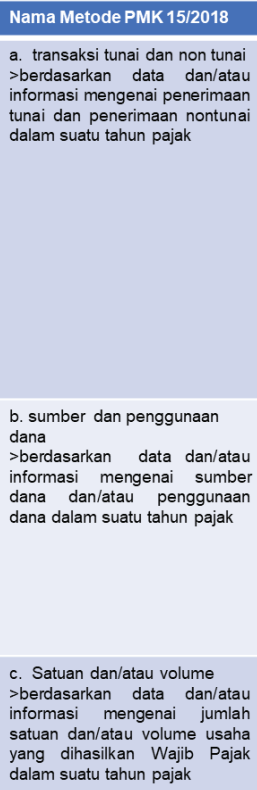

d. Penghitungan biaya hidup >berdasarkan data dan/atau informasi mengenai biaya hidup Wajib Pajak beserta tanggungannya termasuk pengeluaran yang digunakan dalam suatu tahun pajak.

e. Pertambahan kekayaan bersih

>berdasarkan data dan/atau informasi mengenai kekayaan bersih pada awal dan akh tahun dalam suatu tahun pajak

f. SPT atau hasil pemeriksaan tahun pajak sebelumnya tahun pajak sebelumnya >berdasarkan data SPT ata sebelumnya

g. Proyeksi nilai ekonomi >dilakukan dengan cara memproyeksikan nilai ekonomi dari suatu kegiatan usaha pada saat tertentu pada suatu tahun

h. Penghitungan rasio >berdasarkan persentase atau rasio pembanding.

\section{SE-65/PJ/2013}

Pendekatan Transaksi Tunai dan Bank

Penghasilan bruto seharusnya

Jumlah semua penerimaan bank

+Saldo AkhirKas

$+P P h$ yang dipotong/dipungut pihak lain

+Pengeluarantunai

+ Saldo Awal Kas

-Penerimaan yang bukan penghasilan*

-Penerimaan yang bukan objek pajak

-PPN dipungut sendin ${ }^{\star \star \star}$

Tidak diatur dalam kondisi apa metode digunakan

Pendekatan Sumber dan Penggunaan Dana

Saldo awal kas/bank + Sumberdana = Saldo akhirkas/bank + Penggunaandana

Penghasilanbruto = Sumber dana (dalam hal terdapat penambahan dan/atau pengurangan harta dan/atau utang yang belum termasuk dalam sumber dana maka supaya diperhitungkan) digunakan dalam kondisi apabila terdapat data: a.sumber pendanaan kegiatan usaha Wajib Pajak baik intern maupun eksternal.

b. penggunaan dana Wajib Pajak baik untuk kegiatan operasion maupun penambahan harta.

\section{Pendekatan Satuan dan/atau Volume}

Dalam hal volume usaha dalam setahun dapat diidentifikasi maka peredaran usaha setahun dihitung dengan cara sebagai berikut: Peredaran Usaha $=$ Volume Usaha $x$ Harga Jual sangat tepat digunakan apabila jenis barang dan/atau jasa yang dikelola Wajib Pajak terbatas dan harga relatif stabil sepanjang tahun atau terstandardisasi/ ditetapkan pada suatu harga tertentu

\section{Pendekatan penghitungan biaya hidup}

Penghasilan $=$ Pengeluaran Biaya Hidup

Pengeluaran biaya hidup, dapat dikelompokkan menjadi sebagai berikut: konsumsi rumah tangga; transportasi; pendidikan kesehatan; rekreasi, dan pengeluaran lainnya

Tidak diatur dalam kondisi apa metode digunakan. Namun pembahasan menegaskan bahwa metode ini digunakan pada orang pribadi

Pendekatan pertambahan kekayaan bersih

Penghasilan Bruto

Kekayaan Bersih akhirtahun

-Kekayaan Bersih awal tahun

+Biaya Hidup

-Penghasilan bukan objek/PPhFinal

Tidak diatur dalam kondisi apa metode digunakan.

Tidak Diatur

Tidak Diatur

Pendekatan rasio

Pench $x$ rasio

Basis data adalah data awal yang dimiliki oleh Pemeriksa Pajak baik yang berasal dari internal Wajib Pajak pada tahun pajak yang sedang diperiksa atau tahun pajak yang lain, maupun yang berasa dari pihak eksternal, misalnya: peraturan perpajakan yang mengatur mengenai benchmarking, publikasi komersial, hasil pemeriksaan; dll

digunakan dalam kondisi:

a.terdapat data yang dapat digunakan sebagai pembanding dan/atau penghitungan rasio baik dari DJP, Wajib Pajak, maupu dari pihak lain.

b.kegiatan usaha Wajib Pajak dapat dibandingkan dengan rasio yang diperoleh.

Rekomendasi
Adopsi SE-65/PJ/2013 tanpa modifikasi.
Penghasilan bruto:
+Saldo AkhirKas/Bank
+PPh yang dipotong/dipungut pihak lain *
+PengeluaranKas/Bank
+Saldo Awal Kas/Bank
-Penerimaanyang bukan penghasilan*
-Penerimaanyang bukan objek pajak*
-PPN dipungut sendiri*
+Dilakukan apabila WP memberikan bukti potong/pungut dan transaksi
Kondisi pemilihan metode (OECD, 2006):
1. Terdapat data buku kas dan/atau buku bank yang lengkap (diketahui saldo awal,
saldo akhir, total pengeluaran secara utuh, tidak ada informasi yang terpotong);
2. Penghasilan secara kredit tidak lebih dari $50 \%$;
3. WP melakukan setoran seraca periodik ke bank yang berasal dari income-producing
activity;

Modifikasi SE-65/PJ/2013 dengan menambahkan komponen biaya sehingga didapatkan peredaran bruto:

Peredaran Bruto $=$ Penggunaan Dana - SumberDana + Biaya

Kondisi pemilihan metode (OECD, 2006):

1. WP terindikasi memiliki pengeluaran yang melebihi penghasilan yang dilaporkan

2. terdapat sumber kas yang tidak dikelola dalam rekening bank:

3. terdapat pembayaran biaya yang dilakukan dengan kas tanpa melalui bank;

4. data pertambahan/penurunan harta dan/atau utang diketahui; dan

5 . data biaya diketahui;

\section{Adopsi SE-65/PJ/2013 tanpa modifikasi. \\ Volume usahax Harga Jual \\ Kondisi pemilihan metode $($ OECD, 2006): \\ 1. Diketahuijumlah barang dan harga per unit: \\ 2. jenis barang sedikit; dan \\ 3. hargajual relatif stabil dalam satu periode.}

Adopsi SE-65/PJ/2013 hanya untuk WP Orang Pribadi Non Pengusaha

Penghasilan Bruto $=$ Pengeluaran Biaya Hiduo

Kondisi Pemilihan Metode

1. Hanya dilakukan untuk WP Orang Pribadi Non Pengusaha; dan

2. nilai biaya hidup Wajib Pajak diketahui

Modifikasi SE-65/PJ/2013 dengan menambahkan komponen biaya sehingga didapatkan peredaran bruto.

Peredaran Bruto $=$ Kekayaan Bersih AkhirTahun - Kekayaan Bersih awal tahun Penghasilan bukan objek + Biaya

Kondisi pemilihan metode (OECD, 2006)

1. Diketahui kekayaan bersih dalam dua periode; $d a n$

2. Diketahui data biaya:

Diusulkan untuk dihapus dalam jangka panjang karena tidak sesuai dengan praktik internasional dan didasarkan oleh bukti yang tidak relevan (telah lampau). Hanya dilakukan bila terdapat data beberapa tahun sehingga pemeriksa memperoleh pertumbuhan internal WP. Sehingga didapatkan formula sebagai berikut:

Pertumbuhan internal WP. Sehingga didapatkan formula sebagai be

Peredaran Bruto = Pertumbuhan internal $\times$ Peredaran Bruto dari SPT/Hasil Pemeriksaan Tahun Pajak Sebelumnya

Diusulkan untuk mengadopsi metode mark upsesuai praktik internasional.

DasarProyeksiMark Up = Harga Jual per unit/Biaya per unit

Peredaran Bruto $=$ Harga Pokok Penjualan $\times$ DasarProyeksi Mark Up

Kondisi pemilihan metode (OECD, 2006):

1. Persediaan (bukan perlengkapan) sangat menentukan penghasilan, tidak digunakan untuk perusahaan jasa yang kegiatan usahanya tidak memerlukan persediaan yang signifikan

2. Diketahui data harga pokok penjualan, harga jual per unit dan biaya per unit.

Modifikasi SE-65/PJ/2013 dengan membakukan rasio

Fleksibilitas dalam SE-65/PJ/2013 yang tidak terbatas harus diubah agar tidak terjadi kesewenang-wenangan pemeriksa. Formula tetap sama:

Peredaran bruto $=$ Basis data $\times$ Rasio pembanding

Namun, metode ini dapat digunakan jika dan hanya jika terdapat data internal DJP yang secara resmi menetapkan rasio-rasio keuangan Wajib Pajak per-sektor atau per kriteria tertentu lainnya seperti yang telah dilakukan oleh Australia, New Zaeland, Germany, United States sebagimana dituangkan dalam OECD (2006). 